\title{
Dolphinfish fishery around the Maltese Islands*
}

\author{
ADRIANA VELLA \\ Department of Biology, University of Malta, Msida, Malta. E-mail: avel@cis.um.edu.mt
}

\begin{abstract}
SUMMARY: The dolphinfish fishery has constituted and still constitutes an essential part of the Maltese fishing economy. This species appears seasonally in Maltese waters from May-June to December-January, with a peak in October. The fishing techniques used by the Maltese fishermen are still artisinal and concentrate on the juvenile stage of this species present in Maltese waters between August and November. Local research on this species goes back to the 1960s but has not been consistent since then, so more research is required.
\end{abstract}

Key words: Coryphaena hippurus, fishery, Maltese Islands, Central Mediterranean.

\section{INTRODUCTION}

The dolphinfish (Coryphaena hippurus, Linnaeus 1758), called lampuka in Malta, is a species of primary economic importance for the Maltese fishing industry. In the Mediterranean, this epipelagic, top-level predator, agile, migratory and seasonal species is known to grow fast to its maximum age of 3 years and maximum length of over $1 \mathrm{~m}$ (Shcherbachev, 1973; Palko et al.,1982). Its high fecundity provides abundant quantities of juveniles between August and November in the Mediterranean (Massutí and Morales-Nin, 1997). In this region dolphinfish is caught in the swordfish (Xiphias gladius) fishery with drifting long-liners and in the small pelagic fishery via purse seine, but for the Maltese it constitutes an important and historic part of Maltese artisanal fishing (Galea, 1961). Up to a few years ago it was actually the most important fishery due to its appeal to the Maltese public and the abundant catch each year. Fishery statistics

*Received January 20, 1999. Accepted May 12, 1999. show that landings of dolphinfish annually account for $30 \%$ of the total (Farrugia Randon, 1995). Due to its traditional nature most boat owners participate in this seasonal activity, which is organised and managed by the Fisheries Department. Due to the importance of this fishery to the Maltese Islands, Galea (1961) was amongst the first to undertake a study of this fishery in the Mediterranean, while Bannister (1976) incremented the biological knowledge through length-weight and stomach content analyses for this species. The Biology department of the University of Malta has recently started some more research on this species, such as the project on dolphinfish diet also presented in this conference. Wild population identification, assessment and monitoring for conservation are other areas of interest and development at the Department of Biology. Fisheries conservation and management is increasingly becoming necessary, especially for economically important fisheries. For the Maltese Islands the dolphinfish fishery has definitely been and still is a valuable fishery requiring further biological research. 


\section{HARBOURS AND FLEET}

The Maltese fishing fleet may be considered as artisanal. Most of the fleet operates in coastal and small scale fisheries and very few vessels operate in larger scale or in open seas.

In 1998 the total number of licensed fishing vessels was 1792 (1475 in Malta and 317 in Gozo). Out of these only 47 are over 15 metres in length while the rest are below 15 metres in length. The larger industrial vessels are mainly trawlers, long-liners and netters. All the other smaller vessels are considered as multipurpose and undertake different types of seasonal fishing activities, including dolphinfishing. The total numbers of boats and fishermen currently involved in this fishery are 111 boats and 550 fishermen, which amounts to about $6.2 \%$ of the total fishing fleet.

The main landing sites in Malta are Marsaxlokk Harbour and the wholesale fishmarket in Valletta, whilst Mgarr Harbour is the main landing site in Gozo.

\section{FISHING OPERATIONS}

During the month of May, all boat owners whose craft is longer than 6 meters are invited to submit applications for the allocation of a fishing site. When all applications have been received, they are apportioned into different ports/districts. Subsequently all applicants from each district will draw lots for the allocation of a fishing site, with preference being given to full-time fishermen. A licence for using a particular fishing site is then issued by the Department of Fisheries. This license carries the conditions that: i) it is non transferable; ii) the applicant will use only one licensed boat; iii) all fish caught may be sold through the Wholesale Fish Market; iv) each licensee must lay at least 35 Kannizzati (fish aggregating devices, FADs) in a straight line along the way points indicated by the Department. Those fishermen who do not adhere to these conditions will automatically forfeit the right to apply the next year.

In 1998, 98 sites were allocated all around the island except for a corridor. The sites start from 7 miles offshore at intervals of one half or three quarters of a mile, depending on the district. Most of the dolphinfish are captured using FADs. The FADs are small rafts made of floating material which are then anchored to the bottom. These FADs were introduced after it was noticed that the dolphinfish along with other species such as the pilot fish (Naucrates ductor) and the amberjack (Seriola dumerili) tend to aggregate within the canopy of shadow which these floats make. To further augment the number of fish, palm fronds are attached underneath each float.

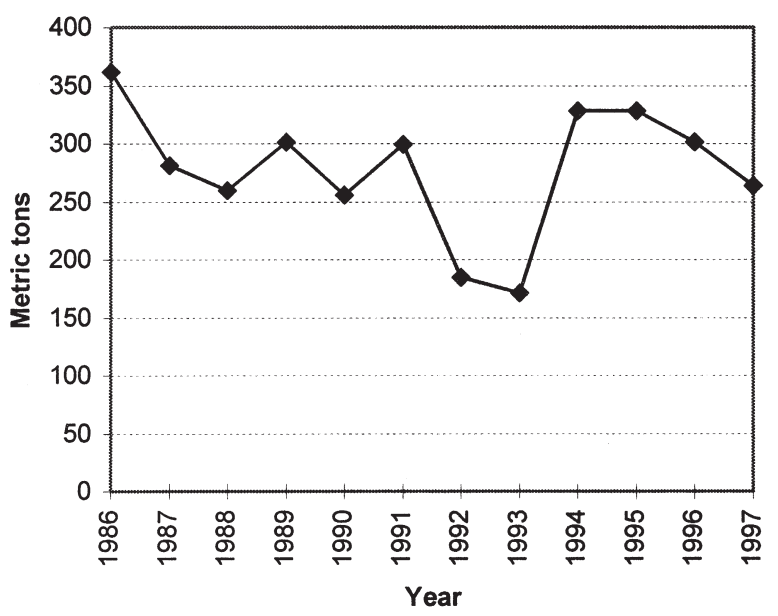

FIG. 1. - Total annual landings of dolphinfish recorded since 1986 in the Maltese Islands

The dolphinfish is caught by surrounding nets similar to a purse seine (Galea, 1961). When the boat is near a FAD various trolls made out of feathers or artificial bait are set and when one fish is caught, a decoy dolphinfish is thrown into the sea to attract any others that may be present under the FAD. When the number of fish present makes it worthwhile, the surrounding operation is then undertaken. Other dolphinfish fishing methods include trolling (catching the fish with a moving lure) and surface long-line (Farrugia Randon, 1995).

\section{LANDINGS}

The annual landings of dolphinfish since 1986 are illustrated in Fig. 1, while Table 1 shows the average monthly landings for the years 1986 to 1996 . These statistics show a peak in dolphinfish landings between September and October. Fig. 2 illustrates the monthly percentage contribution to annual landings for the years 1990 to 1996. Again, with the exception of the year 1994-

TABLE 1. - Mean monthly landings (kg) and standard deviation (S.D.) for the years 1986 to 1996

\begin{tabular}{lrr}
\hline Month & Mean (kg) & S.D. \\
\hline January & 4540 & 3994 \\
February & 445 & 738 \\
March & 0 & 1 \\
April & 0 & 0 \\
May & 37 & 77 \\
June & 96 & 104 \\
July & 30 & 40 \\
August & 22180 & 14494 \\
September & 91115 & 28503 \\
October & 89191 & 35743 \\
November & 56354 & 42818 \\
December & 20866 & 15828 \\
\end{tabular}




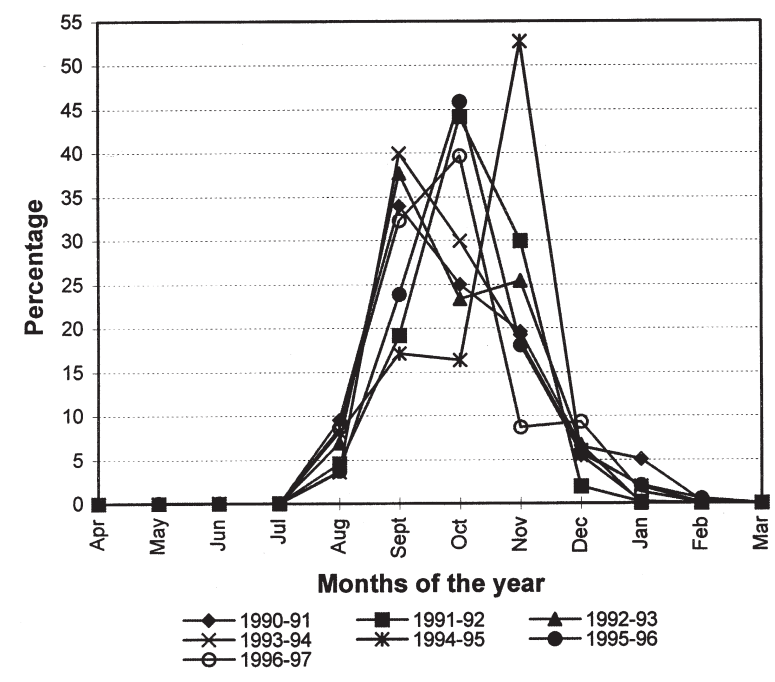

FIG. 2. - Percentage of dolphinfish landings per month between 1990 and 1996

95, the peak in percentage landings is found between September and October.

\section{DISCUSSION}

The migratory nature of dolphinfish inherently makes this species subject to the influences of the different environmental and anthropogenic factors present in each of the regions it transits through. The biological relations and conditions required by this species for its reproduction are starting to be unravelled for the western Mediterranean region (Massutí and Morales-Nin, 1995; Massutí and Morales-Nin, 1997; Alemany and Massutí, 1998), and should develop in other parts of the Mediterranean. Though the dolphinfish presence in the Mediterranean appears to play a key role in the distribution and reproductive biology of this species, more work will be needed to obtain the full picture of this species' biology and distribution. The demonstrated high fecundity of the species and its rapid growth rate presume abundant recruitment. As the Maltese artisinal fishing of dolphinfish targets primarily the juveniles present in Maltese waters, the effects of this fishery on recruitment and abundance of dolphinfish stocks still require assessment. The decline in official Maltese dolphinfish catch observed in recent years may be related to a decrease in full-time fishermen dedicating efforts (169 fishing licenses and sites in 1985 to 96 in 1998) to this fishery as more profitable fisheries such as swordfish and tunny have been developed (Farrugia Randon, 1995). Nonetheless, other possible factors effecting the fishery should be assessed, including weather conditions during the dolphinfish fishing season and the actual fish stock reduction.

\section{ACKNOWLEDGEMENTS}

It is appropriate to acknowledge the assistance of the Fisheries Department of Malta, in particular that of Mr. Frans Caruana and Mr. Charles Busuttil, who were most helpful in the gathering of the raw statistics.

\section{REFERENCES}

Alemany, F. and E. Massutí. - 1998. Note on the First record of larval stages of Coryphaena hippurus (Pisces: Coryphaenidae) in the Mediterranean Sea. Sci. Mar. 62(1-2): 181-184.

Bannister, J.V. - 1976. The length-weight relationship, condition factor and gut contents of the dolphinfish Coryphaena hippurus (L.) in the Mediterranean. J. Fish Biol., 9: 335-338.

Farrugia Randon, S. - 1995. The fishing industry in Malta: past, present, future. Independence Print. ix $+195 \mathrm{pp}$.

Galea, J.A. - 1961. The "Kannissati" fishery. Proc. Gen. Fish. Counc. Mediterr., 6: 85-91.

Massutí, E. and B. Morales-Nin. - 1995. Seasonality and reproduction of dolphinfish (Coryphaena hippurus) in Western Mediterranean. Sci. Mar., 59 (3-4): 357-364.

Massutí, E. and B. Morales-Nin. - 1997. Reproductive biology of dolphinfish (Coryphaena hippurus L.) off the island of Majorca (western Mediterranean). Fish. Res. 30: 57-65.

Palko, B.J., G.L. Beardsley and W.J. Richards. - 1982. Synopsis of the biological data on dolphinfishes, Coryphaena hippurus and Coryphaena equiselis Linnaeus. FAO Fish. Synop., 130, 28 pp.

Shcherbachev, Y.N. - 1973. The biology and distribution of dolphins (Pisces, Coryphaenidae). J. Ichthyol., 13: 182-191. 